\title{
THEOCENTRIC CHRISTOLOGY
}

\author{
By Paul F. KNitTer
}

\begin{abstract}
"Many Christian theologians have moved resolutely away from an exclusive Christology. Today Christology has become (or rebecome) inclusive. ... The theocentric, non-normative understanding of Christ, proposed by the theologians we have studied, will be experienced by many Christians as a threat to the validity of their faith. Therefore, in exploring the possibility of the theocentric approach to Christ, theological caution and especially pastoral sensitivity are necessary."
\end{abstract}

$\lceil N$

N PETER SCHINELLER'S well-known survey of contemporary views of the uniqueness of Christ and the church, as well as in Lucien Richard's more recent review of the same issue, it is clear that many Christian theologians have moved resolutely away from an exclusive Christology. Today Christology has become (or rebecome) inclusive. In unpacking what such inclusivity contains, both of the mentioned studies indicate the breadth, as well as the limits, of contemporary attitudes toward Christ and toward the world outside of Christianity.

Inclusive Christologies tend to affirm a "theocentric universe," one in which God, with divine revelation and salvation, can be present beyond Jesus Christ, within all world religions. That's the breadth. But these Christologies, in different forms, still insist on the "normativity" of Jesus. That's the limit. Jesus constitutes the final, the definitive, the full and therefore the normative revelation of God. He is the "norma normans non normata," the norm beyond all norms. All other revelations and religions, rich and salvific as they may be, do not share this conclusiveness; they must be completed and "normed" by Jesus.

To move beyond such a normative Christology, the current consensus holds, would be either to abandon or to dilute an essential ingredient in Christian experience and tradition. Tom Driver, who, as we shall see, is making such a move, feels he is alone; he finds that even well known liberal theologians (such as Langdon Gilkey, Van Harvey, John Cobb,

Paul F. Knitter is Professor of Theology at Xavier University, Cincinnati. He received the Licentiate in Theology from the Gregorian University, Rome, and the doctorate in theology from Marburg. He is the author of Towards a Protestant Theology of Religions (1974) and numerous articles in journals on the relation between Christianity and world religions. This present article forms part of a book soon to be published by Orbis. 
David Tracy), who are eloquently sensitive to historical relativity and religious pluralism, still put "Christ at the center of things" (Driver, 73). Schineller also points out that while a "non-normative Christology" offers "an attractive position," it "seems somewhat ineffective in an age of pluralism since it affirms that we cannot make decisions among religions and religious savior figures" (Schineller, 565).

A growing number of Christian theologians are clearly and seriously questioning the finality or definitive normativity of Christ and Christianity. Most of them are doing so out of the practical experience of dialogue with other religions. All are suggesting a revision of Christian attitudes that will preserve the distinctiveness of Christ and at the same time allow for a more open and authentic interreligious dialogue. They feel they can admit relativity without sinking into relativism.

Such efforts, admittedly, still make up a minority voice in the Christian churches. To assess what this voice is saying and why its volume seems to be increasing, let us examine three of its principal spokespersons. Each of them has roots in a different Christian tradition: John Hick, originally an evangelical Christian; Raimundo Panikkar, a Roman Catholic priest; Stanley Samartha of the Church of South India. We will call on two other voices critical of a normative Christology: theologians involved in the Jewish-Christian dialogue and representative political/liberation theologians.

While there is an underlying agreement among all these critical views of Jesus' uniqueness, each of them uses a particular perspective in attempting to revise the traditional understanding of Christ's normativity and finality. I will try to bring these individual perspectives into clear focus and indicate, at the end of each section, other contemporary theologians who are using the same perspective. My intent is to show that this minority view is not as minor as one might think.

(1) It was an encounter, both theoretical and personal, with other faiths, that brought about a "Copernican revolution" in John Hick's evangelical Christian faith. Since 1973, he has been promoting a similar revolution for Christianity at large. Its content and intent can be succinctly summarized. Like Copernicus' model of the universe, it

involves an equally radical transformation in our conception of the universe of faiths and the place of our own religion within it ... [It demands] a paradigm shift from a Christianity-centered or Jesus-centered to a God-centered model of the universe of faiths. One then sees the great world religions as different human responses to the one divine Reality, embodying different perceptions which have been formed in different historical and cultural circumstances (Hick, 1973: 131; 1980b: 5-6).

Hick clearly recognizes that "this paradigm shift involves a reopening of the Christological question" (1980b: 6). Admitting that "this must be the most difficult of all issues for a Christian theology of religions" 
(1973: 148), he works out a solution that allows Christians to continue to adhere to Christ as their unique savior without having to insist that he is necessarily unique or normative for others. Hick's main device for doing this, and his main contribution to a theocentric, non-normative Christology is his insistence that Christian belief in the incarnation and in the divinity of Jesus is mythic and therefore not only allows but demands reinterpretation.

Talk about Jesus as the Incarnation of the Word and as the Son of God was, Hick tells us, one of the many symbolic-mythic models used by the early Jesus-followers to try to express what he meant for them. This mythic interpretation turned out to be "the essential Christian belief," the hallmark of Christian identity. Hick insists, however, that it was not so in the very beginning. He makes much of the "all but certain" consensus of biblical scholars that Jesus did not designate himself Messiah or the Son of God, nor accept any such confession about himself from others $(1980 \mathrm{a}: 184 ; 1973$ : 113-114). Tracing the development of the myth of incarnation, Hick finds its embryonic form in the Jewish model of "Son of God," a title often used for the Messiah which, however, could be applied to any extraordinary religious person; it indicated uniqueness, but not exclusivity.

As the early community moved into the Greco-Roman culture, the image of the Son of God was tightened into the notion of incarnation and unique deification. "Ideas of divinity embodied in human life [were] ... widespread in the ancient world ... so that there is nothing in the least surprising in the deification of Jesus in that cultural environment" (1977: 174). This deification process is evident already in the Gospel of John, but it was especially in the conciliar debates of the ensuing centuries, which drew heavily on Greek philosophical concepts and worldview, that the mythical images of "son of God" and "incarnation" were ontologized into absolute and exclusive categories. Thus took place "the very significant transition from 'Son of God' to 'God the Son,' the Second Person of the Trinity." Hick does not at all consider this process a falsification of the Christian experience. It was natural that the early community try to express its experience of Jesus "in the language of absolutes." Jesus as the Son of God, consubstantial with the Father, was "an effective way, within that cultural milieu, of expressing Jesus' significance as the one through whom men had transformingly encountered God" (1977: 172, 175-176; 1973: 116).

But the myth of the incarnation is not so effective today. One of the chief problems with it is that, when taken literally, it leads to all the uncomfortable "onlys" in Christian self-consciousness: Christ is the "only Savior" or the "only final norm" for all other religions. So Hick urges not that belief in the incarnation be done away with (as some of his critics have accused), but that it be taken as a myth, that is, not literally but seriously. He finds precedent for his hope that this will take place. "Christianity will ... outgrow its theological fundamentalism, its literal interpretation of the idea of the incarnation as it has largely outgrown its biblical fundamentalism" (1977: 179-180, 183-184). 
In the way Hick explains his interpretation of the meaning of the myth of the incarnation, he often exposes himself to ready misunderstanding and criticism. He states that language about Jesus as the incarnate Son of God is not meant to be a "factual statement" about "empirical, metaphysical" realities. The imagery of incarnation "lacks any non-metaphorical meaning." "The real point and value of the incarnation doctrine is not indicative but expressive, not to assert a metaphysical fact but to express a valuation and evoke an attitude" (1977: 177-178; 1968: 32).

But Hick does not mean that the myth of the incarnation expresses only an attitude, only a personal response, as if there were no reality outside of the attitude. In more technical terms, he is not denying that there are any "cognitive claims" to the myth of the incarnation. He is not reducing the traditional ontological Christology to a functional Christology. For him, there are facts that constitute the content and the cause of the myth. If people began to talk about God incarnate in Jesus, it was because they experienced him to be "so powerfully God-conscious that his life vibrated, as it were, to the divine life; ... he was so totally conscious of God that ... [others] could catch something of the consciousness by spiritual contagion.... He was a soul liberated from selfhood and fully open to the divine Spirit." Although Hick believes that Jesus grew into this consciousness, that it was not given him pre-packaged from above, still Hick is making the "factual statement" that this is what Jesus was (1977: 172, 1973: 114-116). Incarnationlanguage refers not just to something that happens in us, but to something that happened in Jesus.

Even though Hick holds that "metaphysical facts" are not the "main point" of the incarnation, he does offer his own metaphysical commentary on what the myth means. Trying to move beyond the Chalcedonian categories drawn from an Hellenic metaphysics of substance, he views the divine nature not as a quantity of substantial stuff, but as an activity carrying out a purpose. If, as Christianity has always held, this activity is Agape ("God is love"-I John 4:8), and if this love is at work in history "from the inside," then someone described as the incarnation of God would be a clear case of the "inhistorisation" of the Divine Agape. There would be a "numerical identity" between God's Agape and Jesus. "Jesus' Agape is not a representation of God's Agape; it is that Agape operating in a finite mode; it is the eternal divine Agape made flesh, inhistorised" (1973: 148-158).

With such a metaphysics of the incarnation, Hick feels, room is left for other religions and other saviors. He explains that if we understand the incarnation "as a temporal cross-section of God's Agapeing," it is "not the entirety of that of which it is a cross-section." Or, more clearly, "We want to say of Jesus that he was totus deus, 'wholly God,' in the sense that his Agape was genuinely the Agape of God at work on earth, but not that he was totum dei, 'the whole of God,' in the sense that the divine Agape was expressed without remainder in each or even in some of his actions" (1973: 159). 
So, according to Hick, by understanding the incarnation as a myth, Christians can declare that God is truly to be encountered in Jesus, but not only in Jesus. Furthermore, they can announce that Jesus is the center and norm for their lives, without having to insist that he be so for all other human beings. Such a Christology lays the foundation not only for the possibility but the necessity of interreligious dialogue.

Examples of other theologians who make use of Hick's perspective, that is, the mythic language of the incarnation, as a means for working toward an interreligious dialogue based on a non-normative Christology are Monika Hellwig (we will hear more from her in the following section) and John A. T. Robinson who, like Hick, interprets the "word pictures" of the incarnation to mean that Jesus was "totus deus, the one who is utterly expressive of Godhead," not "totum dei, the exhaustive revelation" of God (Robinson, 1979: 104, 120). ${ }^{1}$

(2) Raimundo Panikkar is one of the most profound and eloquent, as well as one of the most experienced, advocates of a new Christian attitude toward other religions and of a new Christology which would be consistent with that attitude. As the son of a Spanish Roman Catholic mother and an Indian Hindu father, he grew up in two religious traditions. His life of faith and scholarship has continued to be nurtured by both traditions.

For the last two and a half decades, Panikkar has urged what he calls "an ecumenical ecumenism." Like Christian ecumenism, it seeks to promote among all world religions an ever greater "unity without harming diversity." Similar to what Christian ecumenism recognizes among the churches, this interreligious dialogue recognizes among all the world religions a common source and sustenance (Panikkar terms it "the fundamental religious fact"), which exists and can be recognized, however, only in the diversity of the religions. Paradoxically, religious unity, for Panikkar, can be promoted only if the differences among the religions are respected. Still, such unity and cooperation among religions is impossible if any one religion professes to have the "monopoly" on the fundamental religious fact. In other words, if the dialogue is to work, no religion can enter it claiming a final or unique normativity for all other religions (Panikkar, 1973a: 115, 131; 1974; 517; 1978: 2-23; 1981: 19, 23-24).

\footnotetext{
'Robinson points out the dangers of relativism he finds in Hick's approach to other religions; and in no way does he wish to jettison the doctrine of the incarnation as, he thinks, Hick and other contributors to the Myth Of God Incarnate seem to. Still, with Hick, he interprets the mythic language of the incarnation to mean not that Jesus is "of one substance" (Homoousios) but "of one love" (Homoagape) with the Father (1979: 102, 116-117, 119-121). While Robinson is staunchly opposed to "an absolutist, exclusivist or triumphalist assertion of the uniqueness of Jesus as the Christ," he makes the "humble confession" that for him Jesus of Nazareth incarnates and expresses the divine Agape "more fully than ... any other such focal figure." But he insists that this is a personal confession, not a metaphysical declaration. It, like Christ himself, bears an inescapable "provisionality." The Christian's personal confession that Jesus is the clearest focus of God's love is "always to be clarified, completed, and corrected in dialogue" (1979: 125-129; 1973: Chapter 7).
} 
Especially in his more recent statements, Panikkar has recognized that this ecumenical ecumenism places painful strains on present-day Christological benefits. Our new age of religious pluralism demands "an authentically universal Christology." Panikkar's distinctive contribution to such a universal, theocentric, and non-normative Christology is grounded on his distinction between the universal Christ and the particular Jesus. Panikkar's notion of the universal Christ, as distinguished from Jesus, preserves, he feels, the substance of the traditional Logos or Wisdom theology and illumines it by today's cross-cultural religious experience (1973a: 127).

"Christ is ... a living symbol for the totality of reality: human, divine, cosmic" (1981: 27). This totality of reality is what he calls the "primordial theandric fact," or more recently, the "cosmotheandric reality." These terms try to express "that intimate and complete unity ... between the divine and the human." Panikkar explicitly calls this unity a "non-dualist vision." God and the finite world make up a unity, not monistic, but neither dualistic (1973a: 115-116; 1973b: 71, 74; 1981: 27).

Man and God are neither two nor one ... There are not two realities: God and man (plus world); but neither is there one: God or man ... Reality itself is theandric ... God and man are, so to speak, in close constitutive collaboration for the building up of reality, the unfolding of history and the continuation of creation ... God, man, and the world are engaged in a unique adventure and this engagement constitutes true reality ... theandrism is in a paradoxical fashion (for one can speak in no other way) the infinitude of man ... and the finitude of God (1973b: 74-75).

Christ, for Panikkar, is both symbol and substance of this dynamic non-dualistic unity between God, humanity, and world. Christ, therefore, is synonymous with "God the Son, the Logos." The Christ as the Logos is the external expression, the creative communication of the Ultimate, "whatever God does ad extra" (1981: 169). Panikkar piles up traditional imges to try to express the breadth and the intimacy of this divine activity. Christ is "that from which the World comes forth, the Alpha and Omega ... the historical action of divine providence that inspires Mankind in different ways according to time and place, and directs human life ... towards its fullness...." There is, then, only one Christ, "only one link, one mediator between God and the rest, between the one and the many.... Between these two poles everything that functions as mediator, link, 'conveyer' is Christ." This Christ is both divine and human, "really 'human,' or rather worldly without ceasing to be divine ... a reality which not only connects the two poles, but which 'is' the two poles without permitting them to coalesce." The Christ, therefore, is the ground of divinity within all humanity; "the 'vocation' that summoned man into being destined him from the very beginning to be the Son of God, one with the only Son" (1981: 48-49, 155-159, 165, 169; 1973b: 53, 73).

Panikkar's notion of the universal Christ forces questions about the historical Jesus. What is the relation between the two? At this point 
Panikkar reveals where he agrees with and where he steps beyond most current Christological models. With theologians like Rahner and Cobb, he affirms that the Logos or Christ, eternal and universal, has been incarnated in Jesus of Nazareth. But he parts company with them in refusing to maintain that such an incarnation has taken place solely, finally, definitively, normatively in Jesus. This refusal signals a clear change in his own views. In the first edition of his Hidden Christ (1964), Panikkar still held that "a full Christian faith is required to accept ... [the] identity" between Christ and "Jesus the Son of Mary." This made Christianity "the place where Christ is fully revealed, the end and plentitude of every religion" (1964: 145; 1973b: 55). Since the early '70s, however, he has silenced such talk of "identity" and "plentitude," and rejected all models of encounter between Christianity and other religions that presume, from the outset, the fulfillment of other religions in Christianity (1981: 75-96). ${ }^{2}$

Panikkar now states clearly that no historical name or form can be the full, final expression of the Christ. "As the universal symbol for salvation [Christ] cannot be objectified and thus reified as a merely historical personage." This means that "Christ the Savior is . . . not to be restricted to the merely historical figure of Jesus of Nazareth." "Though a Christian believes that 'Jesus is the Christ'.... this sentence is not identical to 'The Christ is Jesus." Jesus, therefore, is a concrete historical name for the "Supername," that is, the Christ, which is always "the name above every name" (Phil. 2:9); (1972: 52-62; 1973b: 53; 1981: 14, 27).

In admitting the limitations of the historical Jesus, Panikkar in no way intends to downplay his necessity-or the necessary role of particular mediators in all religions. The universal Christ, the cosmotheandric fact, can become real only through some particular, historical form; it must take on a concrete name. For himself, as for all Christians, he recognizes that Jesus is the ultimate form of Christ: "this Lord [Christ] whose Lordship can appear in innumerable forms has taken for me an ultimate form which is indissolubly connected with Jesus of Nazareth" (1972: 64; 1981: 7).

Panikkar is convinced, however, that a Christian can make such a personal confession and at the same time acknowledge that "all religions recognize in one way or another" this Christ. The name above all names, that is, the Christ, can go by many historical names: Rama, Krishna, Isvara, Purusha, Tathagata (1973b: 53-54; 1981: 27, 48). “Jesus . . . would be one of the names of the cosmotheandric principle, which has

\footnotetext{
${ }^{2}$ This turning point in Panikkar's thought is found especially in "The Category of Growth" (1973a), Salvation In Christ (1972) and in the completely revised edition of the Unknown Christ (1981). Panikkar states that he would have liked to be "much more radical" in this new edition but, for the sake of continuity and "the rhythm of history," held back (30).
} 
received practically as many names as there are authentic forms of religiousness and which at the same time finds an historically sui generis [special] epiphany in Jesus of Nazareth" (1972: 71-72).

A number of other contemporary theologians, in their efforts to elaborate a non-normative Christology, make distinctions similar to the one Panikkar draws between the universal Logos or Christ and the historical Jesus, such as Wilfred Cantwell Smith, who urges Christians to use the adverb "really" rather than "fully" when they speak of God being revealed in Jesus (175); Don Cupitt, who explicitly holds that while there is surely only "one Jesus," there can be "many Christs" $(1972,1975)$; John Macquarrie, who proposes a model for interreligious dialogue based on "commitment and openness"- total commitment to Jesus and radical openness to other revelations beyond Jesus (1979); Thor Hall who calls upon Christians to relativize the particularity of the incarnation [Jesus] and to universalize the principle of incarnation [Christ], and therefore to "consider the Christ-principle capable of self-realization in a plurality of Christ-events" $(124-125){ }^{3}$

(3) Stanley J. Samartha speaks out of a long history of ecumenism, both Christian and interreligious. An Indian by birth, presbyter of the Church of South India, he served as Director of the World Council of Churches' Program on Dialogue with People of Living Faiths and Ideologies from 1968-1980. Throughout his life, Samartha has advocated dialogue among world religions as the demand of our age. As to the theological grounds for this dialogue, it is often difficult to pinpoint his own opinions, especially in his earlier writings, most of which report the views of the WCC. He seems to have endorsed the theological framework of the WCC approach to other faiths during the '50s and '60s. This was a "cosmic Christology," which saw the saving light of Christ shining within all religions but emanating, fully and normatively, from the historical Jesus (1974). In his more recent statements, during the last half of the 1970s, Samartha seems to have changed his tone. It is much the same change of tone we noted in Panikkar. Samartha is now

\footnotetext{
${ }^{3}$ For Don Cupitt, the notion of the finality and absoluteness of Christ is a discardable element in the mythic model with which Jesus was first understood, part of the "eschatological scheme ... a view of time peculiar to the Jews." In his own reinterpretation of Christ, Cupitt explicitly adopts a Logos Model. Instead of a Christology of Jesus as the final, only begotten Son of God, he proposes a Christology of Jesus as the Word of God. With such a model, Jesus is final not in himself but "because of the way he bears witness to what is final and unsurpassable." Cupitt urges "that talk of Christ must either break away from an exclusive association with Jesus of Nazareth or he severely pruned back" (1975: 618-622, 626-627; 1972: 137-139).

John Macquarrie, especially in his earlier writings, holds that for Christians to claim that their "particular revelation ... is the touchstone and norm by which all other revelations whatsoever must be judged" is "not only morally but intellectually objectionable ... The notion of a normative revelation must be rejected" $(1964: 39,44)$. While, in more recent statements, Macquarrie calls Jesus "the definitive focus of God's acting and presence in the world" (i.e., the Logos) it is clear that he intends this "definitiveness" to describe the quality of Christian commitment to Christ (1979: 347-355).
} 
suspicious of all Christian approaches to other religions based on a theory of anonymous Christianity or cosmic Christology (1981:35).

Like Panikkar, Samartha has come to question the absolute finality and universal normativity of Christ. His guiding argument for doing so, and his distinctive contribution to a non-normative Christology, is his insistence that in light of God as total Mystery, as absolute Other, no religious figure or religion can call itself the final and full word. "The Other relativizes everything else. In fact, the willingness to accept such relativization is probably the only real guarantee that one has encountered the Other as ultimately real." So Samartha urges a model for interreligious encounter that will "recognize God alone as Absolute and ... [will] consider all religions to be relative" (1982: 151-152; 1981: 20-30).

In relativizing all particular religious figures and revelations, Samartha, again like Panikkar, does not intend to deny their necessity or to reduce them to a common denominator. The Mysterious Other must confront us through particular mediations. Samartha clearly rejects any model for dialogue which argues that "all particularities [are] equally valid" and which demands "that no particularity should claim universality" (1981: 29). Still, while each particular revelation is genuinely different, while each may claim a relevance for other religions, each religion and each divine revealer remains limited. "A particular religion can claim to be decisive for some people, and some people can claim that a particular religion is decisive for them, but no religion is justified in claiming that it is decisive for all" (1982: 153). Samartha warns explicitly that no religion, including Christianity, can claim "finality" (1981: 36).

Samartha warns against a "Christomonism" which has infected Christian doctrine and which so absolutizes Jesus that it turns him into "a kind of cult figure over against other religious figures." Christians must never forget that "in the incarnation God relativizes himself." Instead of a Christomonistic approach to other religions, Samartha advocates a theocentric approach, which, he holds, will be more faithful to the original message of Jesus himself (1981: 27).

With such a theocentric model for understanding and encountering other religions, based on a non-normative Christology, Christians, Samartha concludes, will still be able to hold to their personal commitment to Christ and to their belief in his universal meaning. They will still be able to tell other religions that for them, for Christians "nowhere else is the victory over suffering and death manifested so decisively as in the death and resurrection of Jesus Christ." But such an announcement will be an enthusiastic witness to their own revealer, not a denigrating judgment about other revealers. While Christians continue to carry out what they feel is their universal mission of witnessing to Christ, they will be able to "recognize that their neighbors too have their 'missions' in the same pluralistic world" (1981: 30, 33-34, 36).

Samartha's recognition of the necessary relativity of all religions and 
religious figures before the Mystery of God is a perspective that can be found in most contemporary theologians who are working toward a less Christocentric approach to other religions. Among those who make particular use of this perspective are: Howard Burkle, who insists that we must approach other religions well aware of "the inescapable relativity of all human consciousness" and the inescapable relativization of the Absolute in the incarnation; Donald Dawe and Langdon Gilkey, who find an essential relativity or limitation in all of God's convenants with humankind. ${ }^{4}$

\section{II}

The contemporary dialogue between Christianity and its parent religion, Judaism, contains some of the hardest criticisms of traditional normative Christology. This dialogue is growing, and so is its literature. What follows is only a selective review, with a focus on the Christological question.

Christian participants in the dialogue with Judaism are stirred by the same problem that bothers their colleagues in the dialogue with Hinduism, Buddhism, Islam: the way Christianity's traditional selfunderstanding either writes off or subordinates the value of Judaism. From their own experience of dialogue with Jews as well as from their own experience of what faith in Christ means, these theologians feel there is definitely something wrong with the "supersessionist" approach to Judaism. All of these theologians are convinced that such a model of Christian-Jewish encounter cannot be discarded "unless the church is ready to significantly rethink its traditional interpretations of Christology." More explicitly, they have come to "the conclusion that part of our traditional Christology is severely inadequate and should be perhaps discarded" (Pawlikowski, 1982: 7; id., 1977: 367-368).

Although these theologians take different approaches to this "profound re-evaluation" of traditional Christology ("Single-Covenant" or "Double-Covenant" perspectives) (Pawlikowski, 1982: 8-35; McGarry: 73-98), there is almost unanimous agreement among them that it is difficult, if not impossible, for Christians to continue talking about Jesus as the final Messiah, that is, as he who has brought the Messianic Kingdom and who therefore has realized God's final, definitive salvation for all history. Chastened by the dialogue with their Jewish brothers and sisters, these Christian theologians have come to recognize that according to the Messianic promises, which Jesus is supposed to have fulfilled, the true Messiah cannot be considered only as a perfected individual; he must also bring about a kingdom. And here is where the "facts of history" do not seem to sustain the Christian claim. "Our two thousand

\footnotetext{
${ }^{4}$ Burkle's article is one of the most coherent contemporary statements of how Christians might recognize the relativity of Jesus and all religious figures without necessarily denying their "decisiveness" and universal relevance $(459-460,462,464)$. Dawe and Gilkey would agree (Dawe: 13-33; Gilkey: 139-144). Gilkey, however, is not at all clear as to how far one can go in applying radical relativity to Jesus (see 157-170).
} 
years of human experience" do not allow Christians to maintain that Jesus is the Messiah, the final savior, who has brought about the Kingdom. Christians "can no longer simply claim that the Jewish notion of the Messianic age was realized in the Death-Resurrection of Christ" (Pawlikowski, 1977: 376; Ruether, 1981: 43). Honest dialogue with Jews has forced Monika Hellwig and Rosemary Ruether to admit that in a real sense, Jesus is not yet the Messiah or the Christ. To proclaim that "Jesus is Lord" designates not a fait accompli but a task yet to be accomplished (Ruether, 1972: 22; Hellwig: 49). That rules out any finality or absolute normativity for Jesus.

Most of the authors we have mentioned would follow Ruether's reading of how Christians came to fashion Jesus into an absolute and exclusive savior. In the very beginning, the first Jesus followers (most of them Jews) understood Jesus as he, most likely, understood himself, that is, in a very Jewish, a very eschatological sense. He was a prophet who played a crucial role in proclaiming and bringing about God's future kingdom in the world. But the kingdom did not come. When the early Christians set about trying to understand what this meant for them and for their understanding of Jesus, they transformed the future into the present. The future kingdom was claimed to have been already realized in the history of Jesus, and this historical realization was understood to be carried on in the church. Thus, an exclusive finality was attributed to Jesus and, by extension, to the church. Christ and Christ's church were seen as the only way to God. This, according to Ruether, paved the way for the anti-Semitism, as well as the anti-Buddhism, etc., which was to infect the Christian churches through the centuries (Ruether, 1974: 64-182; id.: 1968).

None of the Christian theologians involved in the dialogue with Jews has worked out a fully developed Christology which would avoid the exclusivism of making Jesus the final Messiah but which would maintain his saving role in preparing for the eschatological future. Some of them, however, offer suggestions and guidelines for such a Christology. Ruether summarizes her own suggestions: "the messianic meaning of Jesus' life ... is paradigmatic and proleptic in nature, not final and fulfilled" (1974:249). Jesus, in what he was and in what he symbolizes, is the "paradigm of hope" for Christians. Keeping alive the memory of his resurrection from the dead, his followers have a basis for their refusal to take evil as the last word and for their hope that God will win in the end. Jesus therefore does not attain a finality that can be captured within history; rather, he points to a finality which is still ahead and toward which we must still work. Ruether recognizes that other paradigms, like that of the Exodus, can carry out this same function (1974: 256; id., 1972: 22; id., 1981: 42-43).

Monika Hellwig, reflecting the approach of John Hick, suggests that a reinterpretation of traditional Christology might well begin with a recognition of the nature of the language used by the early Christians to speak about the divinity and the uniqueness of Jesus. It is "religious 
language," mythic, poetic, used to express "the unknowns in Christian experience of divine intervention." Such language will always remain "elusive" and should not be pinned down to absolute, ontological statements. Hellwig suggests that such language be interpreted phenomenologically, that is, as expressing how Jesus was for Christians their place of radical encounter with God (49).

John Pawlikowski agrees with the general direction of Ruether's and Hellwig's suggestions, but he is more concerned about maintaining some form of uniqueness for Jesus. He locates this uniqueness in the fact that in Jesus the pre-established unity between God and humankind came to "full awareness." Jesus therefore is "crucial" for spreading this awareness among all nations. No other human being "will ever share the same intimacy with the divine nature that existed in the person of Jesus" (1982: 114-115). Yet Pawlikowski goes on to show, at great length, how belief in the incarnational unity between God and humanity was seminally but truly contained in the Pharisaical revolution that was transforming Judaism at the time of Jesus; in many ways, Jesus was part of and continued this revolution (1982: 116-118, 76-107). Pawlikowski also concludes that the "unique" revelation of God in Jesus "is in principle no greater than the sacred acts through which Israel was originally elected." "The revelation at Sinai stands on equal footing with the revelation in Jesus" (1982: 122). What Pawlikowski is saying reflects the general view of most of the authors we have reviewed: if there is something unique or "normative" in Christ that Judaism needs, there is also something unique and normative in Judaism needed by Christianity (Pawlikowski, 1982: 149, 122-123; id., 1977: 385-387; Ruether, 1981: 38-39).

\section{III}

Another clear, even shrill, call for a thorough revision of the traditional understanding of Christ as normative and final comes from the perspective of liberation and political theology, as that perspective is being employed by First World theologians like Dorothee Soelle, Rosemary Ruether, and especially Tom Driver. Their contribution to the development of a non-normative Christology is mainly methodological. In a sense they uncover the method, or an essential element in the method, that is operative in all the proposed revisions of Christology that have been studied so far.

Latin American liberation theologians, as is well known, have developed a praxis-based method for theology, but they have not applied this method to the traditional doctrines of Christ's uniqueness and finality. Tom Driver and Rosemary Ruether have. It amounts to what might be called an "ethical hermeneutics." It means, simply, that we must judge the truth of any Christological statement by its ethical fruits, that is, by the praxis to which it leads. Stated negatively, if a particular belief in Christ either causes or sanctions a Christian practice which, from basic 
Christian standards, would be unethical, something is wrong with that belief (Driver: 22-23; Ruether, 1981: 4).

On the basis of such a method, the ethical report card of traditional Christology is not something one would want to bring home to a God of love and justice. Driver and Ruether maintain that the image of Jesus Christ as "central norm," as "the center of history," as the "one and only" incarnation of God in history has, consciously or unconsciously, caused or condoned a long trail of what must be called sinful attitudes or actions. The most glaring of such sins are the superiority, intolerance, rash judgments that have marked Christians' attitudes toward other religions. "The immoral factor in the 'scandal of particularity' today is its insistence upon a once-and-for-all Christ in a relativistic world. . . . It precludes Christianity's ability to affirm that all people have a right to their place in the sun. . . If the incarnation of God in finite humanity can occur but once, the religious value of all other human history is nil" (Driver: 58,60 ). If not nil, certainly inferior.

Ruether asks theologians like Hans Küng who proclaim that authentic humanity was realized only in Jesus whether they are aware how much such a belief feeds the attitude "that all other peoples have an inauthentic humanity." For Ruether the most convincing piece of evidence for the immorality of traditional normative Christology is Christianity's sordid history of anti-Semitism. "Theologically, antiJudaism developed as the left hand of Christology. Anti-Judaism was the negative side of the Christian affirmation that Jesus was the Christ" (1981: 31). Dorothee Soelle can even describe much of Christology as "Christofascism" in the way it has disposed or allowed Christians to impose themselves upon not only other religions but other cultures and political parties which do not march under the banner of the final, normative, victorious Christ (Driver: 3). Finally, Driver and Ruether would place at least part of the blame for the racism and sexism infecting Christian behavior at the doorstep of a Christology which holds that the perfection of humanity, the full and normative presence of God has been realized only, definitively, in a white male. If the medium is the message, the whiteness and maleness of the medium share in the normativity of the message (Driver: 20, 143: Ruether, 1981: 45-56).

Even if only a portion of such charges are accurate, even if a normative Christology has only indirectly sanctioned, not caused, such unethical conduct, still, these theologians hold, such a Christology must be, at the least, highly suspect. So they call for a "paradigm-shift," in Christology and in Christian attitudes toward other faiths and ideologies. Their suggestions for how such a shift might begin reflect proposals we have already heard. Driver endorses Ruether's call to move Christ from the center of history," where he is "the embodiment of a humanity already made perfect in God," to "the lead edge of history," where he will serve as "a herald of the future" (40). Driver also reflects the views of Panikkar and Pawlikowski when he presents the divinity of Jesus as the realization of a given, ontological non-dualism between God and 
world - a realization, however, that "does not indicate something done once and once only for all time" (54-65).

As already pointed out, an "ethical hermeneutics" colors the method of most theologians who are trying to reinterpret the uniqueness of Jesus in the light of interreligious dialogue. Such a hermeneutics is especially evident among missionary theologians like Duraisamy Amalorpavadas, Ignace Puthiadam, Henri Maurier, Eugene Hillman, Burlan Sizemore, all of whom have been engaged in the actual praxis of dialogue with people of other faiths. They have painfully witnessed how an absolutist or normative Christology has fostered the "cultural imperialism" of the West, how it has roadblocked dialogue and actually been "one of the principal reasons for the disappointing results of missionary work." In view of such unethical effects, these scholars, like the liberation theologians, are calling for a revision of traditional Christology (Geffre: vi). ${ }^{5}$

\section{IV}

The theocentric, non-normative understanding of Christ, proposed by the theologians we have studied, will be experienced by many Christians as a threat to the validity of their faith. Therefore, in exploring the possibility of a theocentric approach to Christ, theological caution and especially pastoral sensitivity are necessary. The views we have described in this study need to be further tested in the forum of theological discussion and through exposure to the ongoing faith of Christian communities.

In conclusion, I would like to present, very briefly, some considerations which, if further explored, might help establish the value and validity of a theocentric, non-normative understanding of Jesus Christ.

(1) The various appeals for a different, a non-normative proclamation of Christ, which we have just examined, are not as drastically new as they may sound. They are, I suggest, part of an evolution that has been going on within Christian consciousness, at least in the mainline Catholic and Protestant churches, since the early part of this centuryan evolution from ecclesiocentrism to Christocentrism and now to theocentrism. The evolution from ecclesiocentrism to Christocentrism began as different Christian churches started to adapt to the environment of Christian ecumenism. Christians began to sense that their ecclesiology, their narrow understanding of the church, was an obstacle to genuine exchange with their fellow Christians. A consensus grew that the church cannot be identified with the Kingdom of God, that is, with the universal grace of Christ. Jesus Christ, not the church, is the center of the salvific universe. Thus, the shift from ecclesiocentrism to Christocentrism took shape.

${ }^{5}$ This entire volume (Geffre) is an expression of missionary dissatisfaction with Christianity's claims for superiority or normativity (see especially Puthiadam). For the negative effects which a normative Christology has on missionary efforts: Ganoczy, Singleton, Maurier. 
More recently, as Christian ecumenism among the churches is broadening into ecumenical ecumenism among all religions, a new awareness has been evolving. Christians are sensing that just as their traditional ecclesiology was an impediment to Christian dialogue, so their traditional Christology, which insists on the finality and normativity of Christ, is an obstacle to interreligious dialogue. The new environment of religious pluralism is forcing Christians to ask whether God is revealed definitively in Jesus, whether the incarnational movement of Divinity is broader than what happened in Jesus Christ. We are on the verge, or in the midst, of this next stage of evolution, from Christocentrism to theocentrism.

(2) Another indication that a theocentric, non-normative Christology need not be considered a foreign body within Christian awareness can be found in many contemporary, well-established Christologies. I think a case can be made that a non-exclusive, non-normative understanding of Christ is implicitly contained in the transcendental Christology of Karl Rahner and in the process Christologies of John Cobb, Schubert Ogden, Norman Pittenger, and David Griffin. Even though both schools make use of different starting points and different conceptual frameworks, they agree in their efforts to show that the incarnation of God in Jesus Christ is not a freak event or an anomaly in human history. Rather, divine incarnation in Jesus represents the fulfillment of what God is doing in all of history, the fulfillment of what we are as human beings. As Rahner puts it, in Jesus human nature "simply arrived at the point to which it always strives by virtue of its essence" (1966: 109-110,117). In Pittenger's words, Jesus is "the One in whom God actualized in a living human personality the potential God-man relationship which is the divinely-intended truth about every man" (114).

Anyone who agrees with this understanding of incarnation must question whether these theologians are really being consistent when they go on to insist that such a total fulfillment of human nature has taken place and can take place only in Jesus of Nazareth. It seems that these transcendental and process views of Christ, which see the incarnation as the perfection of human nature, have established, willy-nilly, the possibility, if not the probability, that what happened in Jesus may have happened elsewhere.

(3) A further endorsement for a theocentric Christology comes from liberation theologians like Leonardo Boff, Juan Sobrino, and Rosemary Ruether. Once again, this endorsement (for Boff and Sobrino) is unintended and implicit. For liberation Christology, as for liberation theology in general, praxis is the foundation and touchstone of theory. This means, according to these theologians, that one can really know who Jesus is, one can know the meaning of his titles, only in the concrete following of Jesus, only in the practice of the Gospel. Furthermore, liberation theologians hold that it is not necessary to have crystal clarity and certainty in one's theory or doctrine about Jesus before one commits 
oneself to living his message. Orthodoxy, in other words, will flow from, and constantly have to be reexamined in, orthopraxis.

If such a liberation method makes sense, it leads to some clear implications concerning the uniqueness of Jesus. One can really know what such titles as "only begotten Son of God" or "one Mediator" and "no other name" really mean, one can know whether they should be understood in a Christocentric or theocentric manner, only in the concrete praxis of following Jesus. One of the most important forms of Christian praxis today, as many churches are admitting, is the task of witnessing to Christ in an authentic dialogue with other religions. This means that Christians can come to an orthodox understanding of how Jesus is unique only in the orthopraxis of dialogue with other faiths. The dialogue will provide doctrinal clarity concerning Jesus' uniqueness. Such clarity cannot be had beforehand. This should not disturb Christians. As liberation theologians point out, one does not have to have orthodox certainty that Jesus is the "one and only" before one can commit oneself to working for the kingdom he announced. It is much more important to follow him than to know and insist that there is no one else like him. "Anyone who is not against us, is with us" (Mk. 9:40).

(4) Some of the most weighted resistance to a theocentric, nonnormative understanding of Jesus is voiced in the name of the New Testament witness. There are, however, elements in the New Testament that allow for, perhaps even call for, a revision of Christians' present understanding of Jesus' uniqueness. For example, New Testament scholars generally agree that there are not one but many Christologies, that no one of them was normative, and that all of them took form through a critical but open exchange with Jewish and Greek culturalreligious images. If this is so, is this not a platform and challenge to carry on the task of developing new Christologies, which will be faithful to but different from the old (as much as John's incarnational Christology confirmed yet went beyond the Synoptics' Son of Man Christology)? And might not a contemporary theocentric, non-normative Christology be considered, possibly, to be a valid new view of Jesus, elaborated as it is in a critical but open dialogue with other religions? This is only a suggestion which, evidently, needs further exploration.

This suggestion takes on greater validity in light of a more important and more secure ingredient of the New Testament message. One of the few issues on which New Testament experts are in full agreement is that the focus and core content of Jesus' original message was the Kingdom of God. Jesus' mission and person were profoundly kingdom-centered, which means theocentric. All his powers were to serve this God and kingdom; all else took second place. Even though he saw his own role as crucial in bringing about that kingdom, the Father and the kingdom remained greater than he.

The bulk of the New Testanent, of course, represents the process by which the proclaimer of the kingdom became the proclaimed. The New 
Testament is evidently Christocentric. Still, the Christocentrism of the New Testment does not lose hold of Jesus' original theocentrism. Even in the three texts in which Jesus is proclaimed as God or as divine (Jn. 1:1; Jn. 20:28; Heb. 1:8-9), an evident subordination is preserved (Brown: 23-28). Even Paul, in urging his radical Christocentrism, reminds his communities that "you belong to Christ, and Christ belongs to God" (I Cor. 3:23). His final vision is "that God may be everything to everyone" (I Cor. 15:28). The New Testament maintains a delicate balance between Christocentrism and theocentrism. Perhaps the suggestions we are making for a new theocentric Christology might regain that balance.

(5) Finally, I believe that an understanding of Jesus that does not insist on his finality and normativity would preserve both the content and intent of the abundant, apparently exclusive claims that the New Testament makes about Jesus ("One Mediator," I Tim. 2:5; "only begotten son of God," Jn. 1:14; "once and for all," Heb. 9:12). With New Testament scholars like Krister Stendahl (14-15) and Frances Young (13), I believe that a case could be made that such expressions are mistreated when they are taken as philosophical, dogmatic language meant to state definitively what is Jesus' place in the structures of reality. Rather, such proclamations are confessional, religious language, or, as Stendahl puts it, "love language." Those who spoke such language were not trying to articulate unchangeable metaphysical dogmas about Jesus; they were attempting, rather, to voice what Jesus had done for them, what it meant to be among his followers, what he might mean for others who would commit themselves to him. Christians mistreat such language, therefore, when they use it as a means to reject or belittle others. "No other name" is primarily a confession of Jesus, not a negation of others.

A non-normative, theocentric Christology, therefore, will be, in the words and advice of $\mathrm{H}$. Richard Niebuhr (39-41), a confessional Christology. It will be both a certain and an open-ended confession of Jesus Christ. It will enable Christians to take a firm position; but it will also require them to be open to and possibly learn from other positions. It will allow them to affirm the uniqueness and the universal significance of what God has done in Jesus; but at the same time it will require them to recognize and be challenged by the uniqueness and universal significance of what the Divine Mystery may have revealed through others. In boldly proclaiming that God has indeed been defined in Jesus, Christians will also humbly admit that God has not been confined to Jesus.

\section{WORKS CONSULTED}

Amalorpavadass, Duraisamy, 1979, "Evangelization and Culture." In Evangelization in the World (Concilium 114), pp. 61-71. New York: Seabury. 
Boff, Leonardo, 1978, Jesus Christ Liberator: A Critical Christology for our Time. Maryknoll: Orbis.

Brown, Raymond, 1967, Jesus, God, and Man. Milwaukee: Bruce.

Burkle, Howard R., 1979, "Jesus Christ and Religious Pluralism." Journal of Ecumenical Studies, 16:457-471.

Cupitt, Don, 1972, “One Jesus, Many Christs?" In Christ, Faith, and History, ed. S. W. Sykes and J. P. Clayton, pp. 131-144. Cambridge: Cambridge University Press.

1975, "The Finality of Christ." Theology, 78: 617-628.

Dawe, Donald G., 1978, "Christian Faith in a Religiously Plural World." In Christian Faith in a Religiously Plural World, ed. Donald G. Dawe and John B. Carman, pp. 13-33. Maryknoll: Orbis.

Driver, Tom, 1981, Christ in a Changing World: Toward an Ethical Christology. New York: Crossroad.

Ganoczy, Alexandre, 1979, "The Absolute Claim of Christianity: The Justification of Evangelization or an Obstacle to It?" In Evangelization in the World Today (Concilium, 114), pp. 19-29. New York: Seabury.

Geffre C. and J. P. Jossua, eds., 1980, True and False Universality of Christianity (Concilium 135). New York: Seabury.

Gilkey, Langdon, 1981, Society and the Sacred: Toward a Theology of Culture in Decline. New York: Crossroads.

Hall, Thor, 1982, The Evolution of Christology. Nashville: Abingdon.

Hellwig, Monika, 1970, "Christian Theology and the Covenant of Israel." Journal of Ecumenical Studies, 7:37-51.

Hick, John, 1968, The Center of Christianity. New York: Harper \& Row. 1973, God and the Universe of Faiths. New York: St. Martin's Press.

1977, "Jesus and the World Religions," In The Myth of God Incarnate, ed. John Hick, pp. 167-185. London: SCM Press.

1980a, "Whatever Path Men Choose Is Mine," In Christianity and Other Religions, ed. John Hick and Brian Hebblethwaite, pp. 171-190. Philadelphia: Fortress.

1980b, God Has Many Names. London: Macmillan.

1980c, "Towards a Philosophy of Religions Pluralism." Neue Zeitschrift für systematische Theologie und Religionsphilosophie, 22: 131-149.

McGarry, Michael B., 1977, Christology after Auschwitz. New York: Paulist.

Hillman, Eugene, 1968, The Wider Ecumenism. New York: Herder and Herder.

1974, "Towards the Catholicization of the Church." American Ecclesiastical Review, 168:122-134.

Marquarrie, John, 1964, "Christianity and Other Faiths," Union Seminary Quarterly, 20:39-48.

1979, "Commitment and Openness: Christianity's Relation to Other Faiths." Theology Digest, 27:347-355.

Maurier, Henri, 1976, "The Christian Theology of the Non-Christian Religions." Lumen Vitae, 21:59-74.

Niebuhr, H. Richard, 1962, The Meaning of Revelation. New York: Macmillan.

Panikkar, Raimundo, 1964, The Unknown Christ of Hinduism. London: Darton, Longmann, \& Todd.

1972, Salvation in Christ: Concreteness and Universality, the Supername. Santa Barbara: Privately Published. (Published in part in: Evangelization, 
Dialogue and Development, ed. M. Dhavomony, pp. 195-218. Rome: Gregorian University Press.)

1973a, "The Category of Growth in Comparative Religion: A Critical Self

Examination." Harvard Theological Review, 66:113-138.

1973b, The Trinity and the Religious Experience of Man. Maryknoll:

Orbis.

1974, “Have 'Religions' the Monopoly on RELIGION?" Journal of Ecumenical Studies 11: 515-517.

1978, The Intrareligious Dialogue. New York: Paulist.

1981, The Unknown Christ of Hinduism, Completely Revised and Enlarged Edition. Maryknoll: Orbis.

Pawlikowski, John T., 1977, "Christ and the Christian-Jewish Dialogue." Chicago Studies, 16: 376-389.

1982, Christ in the Light of the Christian Jewish Dialogue. New York: Paulist.

Puthiadam, Ignace, 1980, "Christian Faith and Life in the World of Religious Pluralism." In True and False Universality of Christianity (Concilium 135), pp. 99-112.

Rahner, Karl, 1966, “On the Theology of the Incarnation." In Theological Investigations IV. Baltimore: Helicon, pp. 105-120.

1978, Foundations of the Christian Faith. New York: Crossroad, pp. 176-321.

Richard, Lucien, 1981, What Are They Saying About Christ and World Religions? New York: Paulist.

Robinson, John A.T., 1973, The Human Face of God. Philadelphia: Westminster.

1979, Truth Is Two-Eyed. London: SCM Press.

Ruether, Rosemary, 1968, "Theological Anti-Semitism in the New Testament." The Christian Century, 85: 191-196.

1972, “An Invitation to Jewish-Christian Dialogue: In What Sense Can We Say that Jesus was 'The Christ'?" The Ecumenist, 10:17-24.

1974, Faith and Fratricide. New York: Seabury.

1981, To Change the World: Christology and Cultural Criticism, New York: Crossroad.

Samartha, Stanley J., 1974, The Hindu Response To the Unbound Christ. Bangalore: Christian Institute for the Study of Religion and Society. 1981, "The Lordship of Jesus Christ and Religious Pluralism." In Christ's Lordship and Religious Pluralism, ed. G. H. Anderson and T. F. Stransky, pp. 19-36. Maryknoll: Orbis.

1982, Courage for Dialogue: Ecumenical Issues in Inter-Religious Relationships. Maryknoll: Orbis.

Schineller, J. Peter, 1976, "Christ and Church: A Spectrum of Views." Theological Studies, 37:545-566.

Singleton, Michael and Henri Maurier, 1979, "The Establishment's Efforts to Solve the Evangelical Energy Crisis: The Fourth Roman Synod and Evangelii Nuntiandi." In Concilium 114, pp. 113-119. New York: Seabury.

Sizemore, Brian A. Jr., 1976, "Christian Faith in a Pluralistic Word." Journal of Ecumenical Studies, 13:405-419.

Smith, Wilfred Cantwell, 1981, Towards A World Theology. Philadelphia: Westminster. 
Sobrino, Juan, 1978, Christology At the Crossroads. Maryknoll. Orbis.

Stendahl, Krister, 1981, "Notes for Three Biblical Studies." In Christ's Lordship and Religious Pluralism, eds. G. Anderson and T. Stransky. Maryknoll: Orbis, pp, 7-18.

Young, Frances, 1977, “A Cloud of Witnesses.” In The Myth of God Incarnate, ed. John Hick. London: SCM Press, pp. 13-47. 